\title{
The Ohrid Framework Agreement and the Multiethnic Future of the Republic of Macedonia
}

\author{
Prof. Dr. Etem Aziri \\ Faculty of Public Administration and Political Science, \\ South East European University, Tetovo, Republic of Macedonia \\ Email: e.aziri@seeu.edu.mk \\ Prof. Dr. Emine Emurllai \\ Faculty of Public Administration and Political Science, \\ South East European University, Tetovo, Republic of Macedonia \\ Email: ee12266@seeu.edu.mk
}

Doi:10.5901/ajis.2014.v3n3p472

\begin{abstract}
Being one of the youngest countries in Europe, the Republic of Macedonia has undergone a specific and quite complicated path since the declaration of its independence in 1991. Once a self named "oasis of peace" it was faced with an internal interethnic armed conflict in 2011 which ended with the signing of the Ohrid Framework Agreement. This agreement has on the other hand become of the main symbols of the internal development of the country during the last decade. Although the OFA has not been treated equally by all interested sides, the fact remains that it is most definitively one of the main documents in the development of the country. Although one might argue that the ethnic Macedonians try to build Macedonia as a country of the Macedonians and the others while the ethnic Albanians treat Macedonia as country of the Macedonians, the Albanians and the others, one truth remains. And that undisputable truth is that Macedonia is a multiethnic, multilingual and multicultural country and its future can be build only on mutual respect. This paper strives to provide a short description of the main reasons behind the OFA and its consequences for the Republic of Macedonia and its multiethnic future.
\end{abstract}

Keywords: Ohrid Framework Agreement, Interethnic relations, multiethnic future

\section{Introduction}

Perhaps the most noted developments since the second world war were the "revolutionary" changes in the ex eastern blok that resulted in a major shift of the political system in these countries, replacement of communism with liberal democracy and the planned economy with a free market economy.

Although changes started in the Eastern European Countries, they were quickly spread to the Ex Yugoslav Federation, a country comprised of people with similar yet different historical, cultural and religious background. Although the many problems that the country had, were skillfully "hidden" by the leadership, after the death of Tito, the reemergence of nationalism and the wish of the bigger nations to dominate others, they sparkled into inter ethnic conflicts that will be remembered for a long time.

Macedonia, being one of the constituent Republics of former Yugoslavia, was without a doubt one of the least developed Republics, but at the same time one of the most attached ones to Serbia. Perhaps due to the similar ethnic composition, the Macedonian political elite seemed to follow all anti-Albanian policies created and declared by certain political circles. This on the other hand, resulted in permanent worsening of the inter-ethnic relations within Macedonia. Such worsened inter-ethnic relations continued to worsen even further after the country's independence due to the major differences in understanding of the concept upon which the country should have been developed between the Albanians and the Macedonians being the two major ethnicities with the country.

In fact, the Albanians were convinced that the Republic of Macedonia should be build as a joint country of the Macedonians, Albanians and the others with mutual respect for each other's history, tradition, culture, language and needs. On the other hand the Macedonian political elite, was keen on understanding Macedonia as an ethnic country of the Macedonians and in many circumstances forgetting that almost half of the population is not declared as ethnic Macedonians.

Most ethnic Macedonian politicians and average citizens alike acknowledge that, historically, ethnic Albanians have been excluded from the country's decision-making processes. Notwithstanding the talk of equality that greeted the 
post-Yugoslav transition of the early 1990s, Albanians were the subject of political and economic discrimination during Macedonia's first decade as an independent state, as they had been in communist times. Albanian power was always nominal, certainly at the elite level. Instead, Albanian power was limited to control of peripheral ministries, a ploy designed to lend the state a veneer of legitimacy in the eyes of Macedonia's largest ethnic minority community, comprising some $25 \%$ of the population. In the framework of this 'nationalized state', Macedonians controlled all major levers of power.

In the same vein, Albanians were underrepresented in the public administration, and use of the Albanian language in parliament and higher education was prohibited. For the Albanian community, which, given its size, felt entitled to the same rights and privileges as the titular nation, the lopsided concentration of power established at independence was a source of great discontent, one which its political representatives proved unable to address through Macedonia's fledgling democratic institutions. ( Ripilovski \& Pendarovski, 2013. P.135).

If we try to present with two or three sentences political situation in Macedonia in the years 1990-2001 and in this context to clarify reports of strained relations (here always thought of Albanian-Macedonian relations) as the main and decisive factor must mention the construction of a ethnocentric model state where the constitution was brought by multiparty parliament without the votes of Albanian deputes, Macedonia will be treated as a state of Macedonians (Slav Macedonian meaning) while all other nations would be ranked as citizens. Constitutional inequality of Albanians and state terror that will be exercised for many years led to the extreme aggravation of the Albanian-Macedonian relations and armed conflict in 2001. The years 1990-2001 were years of great despair for Albanians in Macedonia, but also were years that almost nothing good was introduced to Macedonians too. These years represent the first phase of transition, which means privatization of important state enterprises under a formula that meant the enrichment of individuals and small groups in illegal way, further reduction in living standards, poverty, unemployment, deterioration of interpersonal relations, increasing the number of divorces, delay of the marriage, with one word non perspective situation for all Macedonian citizens regardless of religion or nation. Anti-Albanian policy of Macedonian elite began implementation with a more sophisticated strategy from the beginning of plural life in the country.

The first signs of expressing non tolerance will be identified in pre-election rallies in the first multiparty elections. Rhetoric of political leaders in Macedonia and the anger that they were expressing against Albanians in rallies across the country in many respects resembled the Hitler rallies on the eve of World War II. Slogans "gas chambers for Albanians", "Death to Albanians," Albanians to go to vote in Albania "," We have wait a lot "," This is not Kosovo "," Wake up Macedonians "," clean Macedonia "etc. became the anthem of the state. As a result of disregard of legitimate claims, Albanian population did not participate in the referendum for independence that took place on 8th September 1991, also Albanian deputies didn't voted the country's new constitution in the parliament on 17th November 1991. Response of the Albanian political parties to a total ignorance of the Macedonian structures will be organizing a referendum for politico territorial autonomy which will be held on 11-12 January 1992, and declaring the Macedonian constitution as a document that will became the catalyst of crisis.

In the period 1990-2001 all the requests of the Albanians can sublimed on three issues: equal constitutional status with Macedonians, education in mother tongue at all levels and institutional participation of Albanians in state institutions. Unfortunately Albanian demands permanently were rejected by Macedonian elite and Macedonian state. State responses to these legitimate requests was ignoring and repression. In addition will be stated just chilling cases that rocked the domestic opinion, but also relevant international factor, such as the police activities in Struga in 1992, using tanks against Albanian protesters in Bit Pazar a few days later, the Tetovo University happenings which ended with a victim, the bloody Gostivar events in 1997 were all factors that influenced the starting of the armed Albanian rebellion in 2001 which ended with the signing of the Ohrid Framework Agreement. (Aziri, 2010).

On 8 August 2001 in Ohrid, the leaders of the Republic of Macedonia's main political parties, that since 13 May 2001 had formed a shaky 'National Unity Government', struck a deal which aimed at ending the violent conflict between Macedonian security forces and armed Albanian extremists in the country. The fighting had begun in February 2001 and resulted in more than 200 casualties, among them over sixty Macedonian soldiers and policemen. More than 100,000 persons were exiled or internally displaced, and relations between the ethnic Macedonian majority of the country and the Albanian minority reached a record low (for the course of last year's events see Brunnbauer 2001a). In order to prevent fully-fledged civil war from breaking out, Prime-Minister Ljubcho Georgievski ('Internal Macedonian Revolutionary Organisation-Democratic Party of National Unity', VMRO-DPMNE), Branko Crvenkovski ('Social-Democratic Union of Macedonia', SDSM), Arben Xhaferi ('Democratic Party of the Albanians', DPA) and Ymer Ymeri ('Party of Democratic Prosperity', PDP - the second Albanian party) agreed on a package of wide-ranging amendments to the constitution and far-reaching legislative changes that should meet the Albanians' long-standing demands. The agreement came after 
weeks of intense negotiations, in which two international mediators (Francois Leotard for the EU and James Pardew for the USA) took part. (Brunnbauer, 2002). It should be noted that for a period of time the international community addressed NLA leadership and member as "extremists", while the relevant Macedonian factors called them "terrorists". The fact remains that they have been part of the government for the most time since the end of the conflict.

\section{The Ohrid Framework Agreement}

Essentially, the Ohrid Agreement provides the architectural framework for equitable representation of minorities in public administration, language rights, the strengthening of local government, reintegration of territory held or captured by the NLA, return of refugees, and the conduct of an internationally supervised census. On balance, the agreement preserves the unitary state of Macedonia and its territorial integrity. The agreement may be flawed in many ways, but there are many flawed treaties in Europe that function well in practice. Some Macedonians contend that the constitutional changes introduced a type of consensual democracy that could have a negative impact on the government's efficiency and lead to manipulations regarding the ethnic origins of parliamentarians. They argue that the Framework Agreement promotes collective as opposed to individual rights. Thus, Albanians are now identified as a collective rather than as Macedonian citizens. (Pearson, 2002, p.6)

The Framework Agreement was accepted in principle by both sides in the conflict as the only alternative for Macedonia and its citizens. Some analysts characterized the signing of the Agreement as a date of the signature of peace by the two armed sides or as a beginning of a new history for the two biggest nations in Macedonia. Others viewed this as the last chance for cohabitation between Albanians and Macedonians on this territory. The Macedonian President Boris Trajkovski stated that: "The function of the Ohrid Framework Agreement is to stop the war and to set the foundation for a long-lasting peace". (Aziri, 2008). As will be confirmed by the following text the Ohrid Framework Agreement has played a crucial role in reconfirming the multiethnic, multicultural, multilingual character of the Republic of Macedonia, although much has remained to be done in this field.

\section{The Ohrid Framework Agreement and the Multiethnic Future of the Republic of Macedonia}

Much is to be said when analyzing the importance of the Ohrid Framework Agreement in insuring not only the multiethnic character of the Republic of Macedonia, but as many authors like to say the overall survival of the Republic of Macedonia as an independent country. Having this in mind one might argue that although many aspects have been regulated with the OFA, much has still remained to be done. In fact many issues have arisen when it comes to the implementation of the OFA in certain fields such as the usage of the Albanian language, flag etc. Only a few issues will be tackled in the following text.

One of the starting points when discussing the reforms introduced by the OFA should be a careful analysis of the Preamble of the Constitution of the Republic of Macedonia, table 1.

Table 1. Preamble of the Constitution

\begin{tabular}{|c|c|}
\hline As provided by OFA & The official Preamble \\
\hline $\begin{array}{l}\text { The citizens of the Republic of Macedonia, taking over } \\
\text { responsibility for the present and future of their fatherland, } \\
\text { aware and grateful to their predecessors for their sacrifice and } \\
\text { dedication in their endeavors and struggle to create an } \\
\text { independent and sovereign state of Macedonia, and } \\
\text { responsible to future generations to preserve and develop } \\
\text { everything that is valuable from the rich cultural inheritance } \\
\text { and coexistence within Macedonia, equal in rights and } \\
\text { obligations towards the common good -- the Republic of } \\
\text { Macedonia, in accordance with the tradition of the Krushevo } \\
\text { Republic and the decisions of the Antifascist Peopleís } \\
\text { Liberation Assembly of Macedonia, and the Referendum of } \\
\text { September 8, 1991, they have decided to establish the } \\
\text { Republic of Macedonia as an independent, sovereign state, } \\
\text { with the intention of establishing and consolidating rule of law, } \\
\text { guaranteeing human rights and civil liberties, providing peace } \\
\text { and coexistence, social justice, economic well-being and } \\
\text { prosperity in the life of the individual and the community, ... }\end{array}$ & $\begin{array}{l}\text { Taking as the points of departure the historical, cultural, spiritual } \\
\text { and statehood heritage of the Macedonian people and their } \\
\text { struggle over centuries for national and social freedom as well as } \\
\text { for the creation of their own state, and particularly the traditions of } \\
\text { statehood and legality of the Krushevo Republic and the historic } \\
\text { decisions of the Anti-Fascist Assembly of the People's Liberation } \\
\text { of Macedonia, together with the constitutional and legal continuity } \\
\text { of the Macedonian state as a sovereign republic within Federal } \\
\text { Yugoslavia and the freely manifested will of the citizens of the } \\
\text { Republic of Macedonia in the referendum of September 8th, 1991, } \\
\text { as well as the historical fact that Macedonia is established as a } \\
\text { national state of the Macedonian people, in which full equality as } \\
\text { citizens and permanent co-existence with the Macedonian people } \\
\text { is provided for Albanians, Turks, Vlachs, Romanies and other } \\
\text { nationalities living in the Republic of Macedonia, and intent on ... }\end{array}$ \\
\hline
\end{tabular}


Therefore, it is obviously notable that the Preamble as introduced by the OFA and the one adopted by the Parliament of the Republic of Macedonia are not the same. In fact while the OFA version mentions only the citizens of the Republic of Macedonia, therefore providing for a citizen's character of the country, the official Preamble in the very beginning in the English version uses the term the Macedonian people and in the Macedonian version the "Macedonian Nation" and by the end of the preamble mentions other ethnicities. Although this can be considered a semantic issue by some, the fact remains that in a way the Macedonian ethnicity are mentioned as the main ethnicity which provides the right of equality to other ethnicities.

Perhaps one of the greatest contributions of OFA in this sense is one of its main basic principles "The multi-ethnic character of Macedonia's society must be preserved and reflected in public life". Therefore, the OFA considers the multiethnic character of Macedonia as a starting point in the future development of the country and determines that Macedonia's future can be built only through a reflection of the multiethnic character of the country in public life. Although this is one of the main principles of OFA, having in mind the latest developments in the country, one might argue that instead of using multi-ethnicity as a starting point in building an integrated society, multi-ethnicity is being "misused" as a source of further divisions.

One of the main points in which OFA is usually cited for is the right of the non-majority ethnicities to be treated equally in issues such as employment and access to public finance. In fact in OFA it is clearly mentioned in point 4.1. that "The principle of non-discrimination and equal treatment of all under the law will be respected completely. This principle will be applied in particular with respect to employment in public administration and public enterprises, and access to public financing for business development". In practice, as the reports of the Ombudsman show in most institutions the principle of equal representation has not been respected, especially when it comes to managerial positions. Some of the most noted examples are represented in table 2.

\begin{tabular}{|c|c|c|c|c|c|c|c|c|}
\hline & \multirow[b]{2}{*}{ Total } & \multicolumn{2}{|c|}{ Macedonians } & \multicolumn{2}{|c|}{ Albanians } & \multicolumn{2}{|c|}{ Others } \\
\hline & & & $\mathrm{n}$ & $\%$ & $\mathrm{n}$ & $\%$ & $\mathrm{n}$ & $\%$ \\
\hline \multirow{3}{*}{$\begin{array}{l}\text { The cabinet of the President of the Republic of } \\
\text { Macedonia }\end{array}$} & Managerial positions & 16 & 13 & 81.25 & 3 & 18.75 & 0 & 0 \\
\hline & Non-managerial positions & 28 & 25 & 89.29 & 0 & 0 & 3 & 10.7 \\
\hline & Employees at the body & 44 & 38 & 86.36 & 3 & 6.818 & 3 & 6.82 \\
\hline \multirow{3}{*}{$\begin{array}{l}\text { State Commission for the Prevention of } \\
\text { Corruption }\end{array}$} & Managerial positions & 12 & 10 & 83.33 & 2 & 16.67 & 0 & 0 \\
\hline & Non-managerial positions & 12 & 7 & 58.33 & 3 & 25 & 2 & 16.7 \\
\hline & Employees at the body & 24 & 17 & 70.83 & 5 & 20.83 & 2 & 8.33 \\
\hline \multirow{3}{*}{ Constitutional Court of RM } & Managerial positions & 18 & 14 & 77.78 & 2 & 11.11 & 2 & 11.1 \\
\hline & Non-managerial positions & 7 & 6 & 85.71 & 1 & 14.29 & 0 & 0 \\
\hline & Employees at the body & 25 & 20 & 80 & 3 & 12 & 2 & 8 \\
\hline \multirow{3}{*}{ Supreme Court of RM } & Managerial positions & 26 & 20 & 76.92 & 4 & 15.38 & 2 & 7.69 \\
\hline & Non-managerial positions & 50 & 48 & 96 & 1 & 2 & 1 & 2 \\
\hline & Employees at the body & 76 & 68 & 89.47 & 5 & 6.579 & 3 & 3.95 \\
\hline \multirow{3}{*}{$\begin{array}{l}\text { Macedonian Academy of Sciences and Arts - } \\
\text { Skopje }\end{array}$} & Managerial positions & 5 & 5 & 100 & & 0 & 0 & 0 \\
\hline & Non-managerial positions & 52 & 49 & 94.23 & 1 & 1.923 & 2 & 3.85 \\
\hline & Employees at the body & 57 & 54 & 94.74 & 1 & 1.754 & 2 & 3.51 \\
\hline \multirow{3}{*}{ Ministry of Interior Affairs } & Managerial positions & 214 & 168 & 78.5 & 28 & 13.08 & 18 & 8.41 \\
\hline & Non-managerial positions & 11196 & 8814 & 78.72 & 1891 & 16.89 & 491 & 4.39 \\
\hline & Employees at the body & 11410 & 8982 & 78.72 & 1919 & 16.82 & 509 & 4.46 \\
\hline \multirow{3}{*}{ Ministry of Defense } & Managerial positions & 80 & 72 & 90 & 6 & 7.5 & 2 & 2.5 \\
\hline & Non-managerial positions & 795 & 678 & 85.28 & 83 & 10.44 & 34 & 4.28 \\
\hline & Employees at the body & 875 & 750 & 85.71 & 89 & 10.17 & 36 & 4.11 \\
\hline \multirow{3}{*}{ Ministri of Transport and Communications } & Managerial positions & 62 & 54 & 87.1 & 6 & 9.677 & 2 & 3.23 \\
\hline & Non-managerial positions & 246 & 197 & 80.08 & 41 & 16.67 & 8 & 3.25 \\
\hline & Employees at the body & 308 & 251 & 81.49 & 47 & 15.26 & 10 & 3.25 \\
\hline
\end{tabular}

Another issue that should be addressed is the issue of the multilingual character of the country. In fact Anex A of the OFA provides that the following text should be incorporated in Article 7 of the constitution "Any person living in a unit of local self-government in which at least 20 percent of the population speaks an official language other than Macedonian may use any official language to communicate with the regional office of the central government with responsibility for that municipality; such an office shall reply in that language in addition to Macedonian. Any person may use any official language to communicate with a main office of the central government, which shall reply in that language in addition to 
Macedonian". On the other hand the text of Article 7 of the Constitution is as cited "The Macedonian language, written using its Cyrillic alphabet, is the official language in the Republic of Macedonia. In the units of local self-government where the majority of the inhabitants belong to a nationality, in addition to the Macedonian language and Cyrillic alphabet, their language and alphabet are also in official use, in a manner determined by law. In the units of local self-government where there is a considerable number of inhabitants belonging to a nationality, their language and alphabet are also in official use, in addition to the Macedonian language and Cyrillic alphabet, under conditions and in a manner determined by law". Therefore, the very text of the OFA has not been in full incorporated in the Constitution, leaving in this way much space for open debates regarding the right to use the Albanian language as official. Perhaps this is one of the reasons for the tensioned debated regarding the adoption of the "Law for official usage of the language spoken by at least 20\% of citizens and the units of local self-governance", although in many cases this Law introduced the main principled of OFA regarding this issue to the society in the Republic of Macedonia. Another issue having to do with this aspect is the capacity and the willingness of the mostly ethnic Macedonian employees in the regional offices of the central government to communicate officially in Albanian besides in Macedonian.

\section{Conclusions and recommendations}

The Republic of Macedonia is one of the many multi-ethnic countries in Europe. But, it seems that in the case of the Republic of Macedonia the shared past mostly presents an element of further divisions mostly due to a sort of a "hate' imbedded and developed through generations. The lack of sense for the natural requests of the Albanian national ethnicity on the side of the Macedonian political elites has been one of the most expressed obstacles to the development of the Republic of Macedonia as a truly integrated multiethnic society in which all sides would show proper respect for the needs and wants of the others.

The years of a lack of willingness to show at least minimal respect for the group demands of the Albanian ethnical community and the lack of understanding for even the basic human and democratic right such as the one of using own language and being allowed to educate in their own language, led to the Armed Conflict of 2001 that ended with the adoption of the Ohrid Framework Agreement as a document that should have provided a truly multiethnic future for the Republic of Macedonia and its citizens.

Regardless of the way how different politicians, analysts and policy makers prefer to understand and comment the Ohrid Framework Agreement and its provisions, the fact remains that its "spirit" is embedded in its very text. Without a doubt, there is a reason why the Agreement itself begins with the following text: "The following points comprise an agreed framework for securing the future of Macedonia's democracy and permitting the development of closer and more integrated relations between the Republic of Macedonia and the Euro-Atlantic community. This Framework will promote the peaceful and harmonious development of civil society while respecting the ethnic identity and the interests of all Macedonian citizens". Obviously the "spirit" of OFA that is quite often mentioned by politicians in Macedonia, has to do with building improved relations of Macedonia with the international community preconditioned by the creation of a fully functional multi-ethnic society in Macedonia with respect for all citizens. Therefore it implies building Macedonia as a civic rather than a nation state.

Having this in mind the citizens of the Republic of Macedonia, the political elites and everyone else should be aware of the fact that OFA cannot be considered and treated as a simple document, a framework with a beginning and an end but rather as a living and breathing framework that needs to be kept alive and change alongside with the highly developed international standards. After all one of the basic principles of OFA is "A modern democratic state in its natural course of development and maturation must continually ensure that its Constitution fully meets the needs of all its citizens and comports with the highest international standards, which themselves continue to evolve". As long as OFA is treated as such it can provide for a good basis upon which the future development of Macedonia can be built and created according to the ever enduring multi-ethnic, multi-lingual, multi-cultural and multi-religious character of the country. 


\section{References}

Ripiloski S and Pendarovski S. (2013). Macedonia and the Ohrid Framework Agreement: Framed Past, Elusive Future. PERCEPTIONS, Summer 2013, Volume XVIII, Number 2, pp. 135-161

Aziri E. Inter-ethnic relations in the Republic of Macedonia before and after the Ohrid Framework Agreement. In Balkans: Foreign Affairs, Politics and Socio-Cultures, pp. 131-156

Pearson B. (2002). Putting Peace into Practice: Can Macedonia's New Government Meet the Challenge.

Centre for Regional Policy Research and Cooperation "Studiorum". (2011). Effective Political Participation Of The Small(Er) Ethnic Communities In Local Self-Government In The Republic Of Macedonia.

The Ohrid Framework Agreement

Annual Report of the Ombudsman of the Republic of Macedonia, 2013 